Editorial

\title{
Scoring Systems. A Useful Tool to Resume Urological Surgery During the Covid-19 Pandemic
}

\author{
Hugo Enrique López-Ramos ${ }^{1}$ Herney Andrés García-Perdomo ${ }^{2}$ \\ 1 Pontificia Universidad Javeriana de Bogotá, Hospital Universitario \\ San Ignacio, Bogota, Colombia \\ ${ }^{2}$ Department of Surgery, Division of Urology, School of Medicine, \\ Universidad del Valle, Cali, Colombia \\ Urol Colomb 2020;29:66-68.
}

The rapid worldwide spread of SARS-CoV-2 (COVID-19) infection has generated a significant health crisis. ${ }^{1,2}$ The focus was on the use of health resources to care for COVID19 patients in emergency, hospitalization, and intensive care settings. ${ }^{3}$ On the other hand, the vast majority of hospital institutions canceled face-to-face consultations and elective procedures, generating an impact on patient care. ${ }^{4}$

Most elective urologic surgeries can be delayed without a negative impact on the patient; except for urologic oncology surgeries.

The European Association of Urology (EAU) and the robotics section (ERUS) of the same association, published their recommendations for surgery during the COVID-19 emergency. ${ }^{5}$ Apart from specific recommendations for each case based on programming priorities, they recommend to discuss in a multidisciplinary board previous to take any decision.

Other societies published guidelines for performing surgeries in COVID-19 times; however the focus is to operate what may have a deleterious effect on the patient. These guidelines do not offer a specific pathway to continue consultation and surgery safely for both the professional and the patient.

There are some reports of safe and straightforward systems that classify patients according to their condition, type of procedure, and surgical priority that give us a guideline for reprogramming elective urological procedures. ${ }^{6}$

Prachand et al. ${ }^{7}$ proposed a new scoring system (MedicallyNecessary, Time-Sensitive Procedures - MeNTS) intending to prioritize medically necessary surgeries that should not be delayed due to the COVID-19 hospital crisis. This scoring system comprises 21 plausible factors that may contribute to the most unsatisfactory perioperative outcomes, the risk of transmission of SARS-CoV-2 to health professionals, and the increased use of hospital resources during the pandemic with anchorage values assigned to a scale of 1-5 in objective measures.
The score contains three domains: Procedure, patient, and disease, each of which requires a score (7-35), (6-30), and (8-40), respectively, and finally a total score, ranging from 21 to 105 ( $\sim$ Appendix 1). The higher the score, the greater the risk to the patient, the use of healthcare resources, and the chances of viral exposure to the healthcare team. ${ }^{7}$ The authors proposed a cut-point of 55-57 points, considering that above this value, surgeons need to verify the suitability of the procedure.

Similarly, the Spanish Association of Surgery (SAS) ${ }^{8}$ published a series of recommendations on how to resume elective surgery after passing the peak of the pandemics. They used the Prachand scoring system establishing a cut-off value of 60 points. Above this value, the suitability of the procedures should be reconsidered.

The American College of Surgeons ${ }^{6}$ in conjunction with other scientific societies, suggest the following elements to return to elective surgical activities:

1. The time to return must be consistent with a decrease in the number of cases in the geographic location for at least 14 previous days. Also, hospitalization and intensive care should be available for these patients if it is required.

2. There should be the availability of appropriate exams for COVID-19 in these patients and the professional staff. If it does not exist, it is suggested to establish a contagion prevention plan.

3. All health professionals should be trained in the proper use of personal protection elements. Additionally, there must be the availability of all these.

4. There must be a clear prioritization and organization system, based on scoring systems (eg, MeNTS) in such a way that priority is given to previously canceled cases, as well as to cancer cases that require prompt attention. Additionally, a strategy should be planned in conjunction
Address for correspondence Herney Andrés García-Perdomo, MD MSc EdD, PhD, FACS, Department of Surgery/Urology, School of Medicine, Universidad del Valle, Cali, Colombia (e-mail: editorrevista@scu.org.co).
DOI https://doi.org/ 10.1055/s-0040-1713094. ISSN 0120-789X. e ISSN 2027-0119.
Copyright $\odot 2020$, Sociedad Colombiana License terms de Urología. Publicado por Thieme Revinter Publicações Ltda., Rio de Janeiro, Brazil. Todos los derechos reservados.

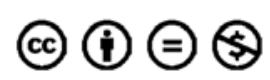


with operating rooms, hospital wards, and intensive care for the arrival of the number of patients requiring surgery.

5. The establishment of protocols for each scenario is essential for an excellent return to activities.

Regarding outpatient follow-up, it is suggested that patients should be discharged in good and stable condition in such a way as to minimize the risk of readmission. Additionally, authors suggest reducing the subsequent controls to the minimum number necessary and also to make use of the information and communication technologies that currently support telehealth, ${ }^{4,9}$ in such a way of reducing hospital visits.

We want to propose a proper pathway of resuming to elective urological activity based on compliance with a strict and safety protocol both in the consultation and in elective surgery; to avoid the collapse of our system and ensure appropriate outcomes for our patients. ${ }^{6}$ The protocol should include rigorous evaluation of patients based on these scoring and classification systems, as well as strict compliance with the biosafety of healthcare personnel. Additionally, the decision of a multidisciplinary board must be considered, given the legal implications that these decisions may have.

\section{Conflict of Interests}

The authors have no conflict of interests to declare.

\section{References}

1 Zhu N, Zhang D, Wang W, et al; China Novel Coronavirus Investigating and Research Team. A novel coronavirus from patients with pneumonia in China, 2019. N Engl J Med 2020;382(08):727-733

2 Wang C, Horby PW, Hayden FG, Gao GF. A novel coronavirus outbreak of global health concern. Lancet 2020;395(10223):470-473
3 CMS. OPENING UP AMERICA AGAIN Centers for Medicare \& Medicaid Services (CMS) Recommendations Re-opening Facilities to Provide Non-emergent Non-COVID-19 Healthcare: Phase I.

4 Garcia-Perdomo H, Beas Sandoval L. La enseñanza en los programas académicos y quirúrgicos en tiempos de COVID-19. Rev Mex Urol 2020;80(02):1-3

5 Ribal M, Cornford P, Briganti A, Knoll T, Gravas S, Marek B. EAU Guidelines Office Rapid Reaction Group: An organisation-wide collaborative effort to adapt the EAU guidelines recommendations to the COVID-19 era [Internet]. European Association of Urology; 2020 [cited 2020 May 10]. p. 1-83. Available from: https://uroweb.org/wp-content/uploads/EAU-Guidelines-OfficeRapid-Reaction-Group-An-organisation-wide-collaborative-effort-to-adapt-the-EAU-guidelines-recommendations-to-theCOVID-19-era.pdf

6 American College of Surgeons. American Society of Anesthesiologists., Association of periOperative Registered Nurses., American Hospital Association. Joint Statement: Roadmap for Resuming Elective Surgery after COVID-19 Pandemic [Internet]. American College of Surgeons; 2020 [cited 2020 May 10]. Available from: https://www.facs.org/covid-19/clinical-guidance/roadmap-elective-surgery

7 Prachand VN, Milner R, Angelos P, et al. Medically necessary, time-sensitive procedures: scoring system to ethically and efficiently manage resource scarcity and provider risk during the COVID-19 Pandemic. J Am Coll Surg 2020;S1072-7515(20) 30317-3

8 Española de Cirujanos A. Recomendaciones De Gestión Para La Vuelta a Normalidad Y “Desescalada” En Los Servicios De Cirugía General En El Contexto De La Pandemia Covid 19 [Internet]. Asociación Española de Cirujanos; 2020. Available from: https://www.aecirujanos.es/Documentos-de-posicionamiento$\mathrm{y}$-recomendaciones-de-la-AEC-en-relacion-con-la-cirugia-yCOVID19_es_1_152.html

9 Simonato A, Giannarini G, Abrate A, et al; Members of the Research Urology Network (RUN). Pathways for urology patients during the COVID-19 pandemic. Minerva Urol Nefrol 2020 
68 Scoring Systems López-Ramos, García-Perdomo

Appendix 1 Medically-Necessary Time Sensitive (MeNTS) OR Procedure Prioritization Worksheet

\begin{tabular}{|c|c|c|c|c|c|}
\hline Procedure & 1 & 2 & 3 & 4 & 5 \\
\hline OR Time & $<30$ minute & 31-60 minute & $61-120$ minute & 121-180 minute & $\geq 181$ minute \\
\hline LOS Anticipated & Outpatient & $23 \mathrm{hrs}$ & 24-48 hour & $2-3 d$ & $\geq 4 \mathrm{~d}$ \\
\hline Post-Op ICU need & Very Unlikely & $<5 \%$ & $5-10 \%$ & $11-25 \%$ & $>25 \%$ \\
\hline Bleeding Risk & $<100 \mathrm{cc}$ & $101-250 c c$ & $251-500 \mathrm{cc}$ & $501-750 c c$ & $\geq 751 c c$ \\
\hline Surgical Team Size & 1 & 2 & 3 & 4 & $>4$ \\
\hline $\begin{array}{l}\text { Intubation Needed to } \\
\text { Perform Procedure } \\
\text { (Probability) }\end{array}$ & $\leq 1 \%$ & $1-5 \%$ & $6-10 \%$ & $11-25 \%$ & $\geq 25 \%$ \\
\hline \multirow[t]{2}{*}{ Surgical Site } & $\begin{array}{l}\text { None of the } \\
\text { following }\end{array}$ & $\begin{array}{l}\text { Abdominopelvic } \\
\text { MIS Surgery }\end{array}$ & $\begin{array}{l}\text { Abdominopelvic } \\
\text { Open Surgery, } \\
\text { Infraumbilical }\end{array}$ & $\begin{array}{l}\text { Abdominopelvic } \\
\text { Open Surgery, } \\
\text { Supraumbilical }\end{array}$ & $\begin{array}{l}\text { OHNS/Upper } \\
\text { Gl/Thoracic }\end{array}$ \\
\hline & & & & $\begin{array}{l}\text { Procedure Score } \\
(7-35)\end{array}$ & \\
\hline $\begin{array}{l}\text { Non-Operative Treatment } \\
\text { Option EFECTIVENESS }\end{array}$ & None available & $\begin{array}{l}\text { Available, }<40 \% \text { ef- } \\
\text { fective as surgery }\end{array}$ & $\begin{array}{l}\text { Available, } 40-60 \% \\
\text { effective as surgery }\end{array}$ & $\begin{array}{l}\text { Available, } 61-95 \% \\
\text { effective as surgery }\end{array}$ & $\begin{array}{l}\text { Available, equally } \\
\text { effective }\end{array}$ \\
\hline $\begin{array}{l}\text { Non-Operative Treatment } \\
\text { Option RESOURCE USE/ } \\
\text { EXPOSURE RISK }\end{array}$ & $\begin{array}{l}\text { Significantly worse/ } \\
\text { not applicable }\end{array}$ & Somewhat worse & Equivalent & Somewhat better & Significantly Better \\
\hline $\begin{array}{l}\text { Impact of } 2 \text { wk delay in } \\
\text { DISEASE outcome }\end{array}$ & Significantly worse & Worse & Moderately worse & Slightly worse & Minimally worse \\
\hline $\begin{array}{l}\text { Impact of } 2 \text { wk delay in } \\
\text { SURGICAL difficulty/risk }\end{array}$ & Significantly worse & Worse & Moderately worse & Slightly worse & Minimally worse \\
\hline $\begin{array}{l}\text { Impact of 6wk delay in } \\
\text { DISEASE outcome }\end{array}$ & Significantly worse & Worse & Moderately worse & Slightly worse & Minimally worse \\
\hline $\begin{array}{l}\text { Impact of 6wk delay in } \\
\text { SURGICAL difficulty/risk }\end{array}$ & Significantly worse & Worse & Moderately worse & Slightly worse & Minimally worse \\
\hline Patient & 1 & 2 & 3 & 4 & 5 \\
\hline Age & $<20$ yo & $21-40$ yо & $41-50$ yо & $51-65$ yо & $>65 y o$ \\
\hline $\begin{array}{l}\text { Lung Disease (asthma, } \\
\text { COPD, Cystic Fibrosis) }\end{array}$ & None & & & $\begin{array}{l}\text { Minimal (rare } \\
\text { inhaler) }\end{array}$ & $>$ Minimal \\
\hline Obstructive Sleep Apnea & Not present & & & $\begin{array}{l}\text { Mild/Moderate (no } \\
\text { CPAP) }\end{array}$ & On CPAP \\
\hline Cardiovascular Disease & None & Minimal (no meds) & Mild (1 med) & Moderate (2 meds) & Severe ( $\geq 3$ meds) \\
\hline Diabetes & None & & Mild (no meds) & $\begin{array}{l}\text { Moderate (PO meds } \\
\text { only) }\end{array}$ & $>$ Moderate (insulin) \\
\hline Immunocompromised* & No & & & Moderate & Severe \\
\hline $\begin{array}{l}\text { Flu-like symptoms } \\
\text { (fever, cough, sore throat, } \\
\text { body aches, diarrhea) }\end{array}$ & $\begin{array}{l}\text { None } \\
\text { (Asymptomatic) }\end{array}$ & & & & Yes \\
\hline \multirow[t]{2}{*}{$\begin{array}{l}\text { Exposure to known } \\
\text { COVID+ Pt (14d) }\end{array}$} & No & Probably Not & Possibly & Probably & Yes \\
\hline & & & & Patient Score (8-40) & \\
\hline \multicolumn{6}{|c|}{$\begin{array}{l}\text { Cumulative MeNTS Score } \\
\text { (Procedure + Disease + Patient) }\end{array}$} \\
\hline & & Range (21-105) & MRN & Pt. Initials & Procedure \\
\hline
\end{tabular}

